imposing figure standing on the threshold between two periods in the history of physics. As long as his pupils live, they will bear an affectionate memory of a great teacher and unselfish friend.

$$
\text { P. P. Ewald }
$$

\section{Mr. Lincoln Ellsworth}

Lincoln Ellsworth, whose death took place at the end of May, was one of the pioneers of polar flying, both in the Arctic and the Antarctic. He was born in Chicago in 1880 and was employed for several years on survey work on Canadian railways, and also as an assistant engineer on goldfields in Alaska. During the First World War he was in the U.S. Army Air Corps.

Ellsworth first became known to a wider public in 1925, when his father decided to finance a flight which Roald Amundsen was planning to make to the north pole in Dornier.Wal flying boats. When near the pole it was found necessary to land on a lead of open water in the polar pack. The take-off, however, proved extremely difficult. One of the flying boats was abandoned, and it was three weeks before the other was again airborne and able to return to Spitsbergen from a farthest north latitude of $78^{\circ} 44^{\prime}$.

Next year Ellsworth again collaborated with Amundsen, who was negotiating for the purchase of an Italian airship, renamed the Norge. Nobile was the technical expert, Amundsen provided the polar knowledge, and much of the financing again came from Ellsworth. The expedition was entirely success. ful. It took off from Kings Bay, Spitsbergen, on June 11, 1926, and after crossing the north pole landed at Teller in Alaska three days later.

Ellsworth's next effort was to assist Sir Hubert Wilkins in plans for a voyage in 1931 from Spitsbergen northwards under the pack-ice in the submarine Nautilus. $\mathrm{He}$ did not himself take part in the expedition, but was one of the party that same summer on the airship Graf Zeppelin on her Arctic voyage from Friedrichshafen over Franz Josef Land and Severnaya Zemlya (Nicholas II Land).

This first contact with Wilkins was the beginning of a long and intimate association, and Ellsworth now turned his attention to the Antarctic, with Wilkins as his adjutant. His first attempts, however, in 1933-34 at the Bay of Whales in the Ross Sea, and in 1934-35 from Snow Hill on the east coast of Graham Land, were unsuccessful ; but next year, with Hollick-Kenyon as pilot in a Northrup machine, the Polar Star, a flight was made from Dundee Island on the north-east coast of Graham Land across Antarctica to the Ross Sea. No less than three landings were made, and the flight, which had begun on November 23, 1935, ended on December 4, when the machine landed on the Ross Brrrier some miles inland from the Bay of Whales. Ellsworth's radio had failed at an early stage in the flight, and in view of the uncertainty arising the British, Australian and New Zealand Governments in collaboration decided to divert Discovery II from her usual oceanographical work. She arrived at the Bay of Whales on January 15 and rescued Ellsworth and his companion, who had been living in an ice cave for six weoks. This flight was the most successful yet made in the Antarctic, and the three landings to wait until the weather improved were a completely new departure in polar flying, representing a striking advance from Ellsworth's flying boat experience in 1925 .
After his trans-continental flight, Ellsworth made one more expedition to the south, in 1938-39, when a flight was made over Princess Elizabeth Land at $12,000 \mathrm{ft}$. along the $79 \mathrm{th}$ meridian to $72^{\circ} \mathrm{S}$. On his return, Ellsworth sold his ship Wyatt Earp to the Australian Government, having by now seen polar flying develop from the first uncertain stages to his own successful flight across the Antarctic continent.

J. M. WORDIE

\section{Miss V. E. Benes}

Vrasta Eva Bentašova was born in Kutna Hora, Bohemia, on December 2, 1919. She studied at the Lycée at Kolin and was a distinguished student in the Pharmaceutical Department of the University of Prague. After holding various provincial appointments she returned to Prague and began to carry out research work on "La sedimentation des Algues", under Prof. Silvestr Prat. In 1947, with the aid of a bursary, she proceeded to Paris and continued her research at the Sorbonne under Prof. W. Plantefol. She published three papers in the Comptes rendus of the Paris Academy of Sciences in 1948 and 1949, her work on Homatococcus pluvialis being an important contribution to our knowledge of the Volvocales. Afterwards, fired with enthusiasm by a visit to the marine station at Roscoff, she began a serious study of the marine algæ, under Prof. J. Feldmann and M. Chadefoud. In 1949 she sailed for Australia, where she collected marine algæextensively on the coasts of New South Wales and made an intensive search for members of the Ceramiales with the view of a detailed study of their life-cycles. Despite her language difficulty she taught easily, and Prof. Burges writes of the active and successful contribu. tion that she made to the study of the algæ in the University of Sydney. Towards the close of 1950, in a serious fall in the laboratory, she fractured her pelvis; but she made a good recovery and returned again to collect on the shores of New South Wales, a locality for which she had developed a deep regard. Perhaps it was too soon for her to venture alone on reefs as difficult as those near the Woy Woy Research Station, for to the dismay of her friends, on March 10 she did not return from the collecting ground.

Prof. Feldmann writes: "Sa tragique disparition qui est venue si soudainement interrompre sa carrière, constitue une perte sensible pour l'Algologie. Mais le souvenir de Vlasta demeurera surtout vivace dans le cœur de ceux qui l'ont connu et ont pu apprecier ses qualités d'esprit et de cœur." LILY NEWTON

WE regret to announce the following deaths :

Prof. J. W. Bigger, during 1924-50 professor of bacteriology and preventive medicine in the University of Dublin, aged fifty-nine.

Harald Blegvad, secretary-general of the International Council for the Exploration of the Sea, on August 22, aged sixty-five.

Brigadier E. M. Jack, C.B., C.M.G., directorgeneral during 1922-30 of the Ordnance Survey, on August 10, aged seventy-eight.

Dr. John.R. Loofbourow, associate professor in the Massachusetts Institute of Technology, known for his work on absorption spectroscopy and the biological effects of radiation, on January 23, aged forty-seven. 